\title{
Christian Economic Thought in The Netherlands
}

\author{
Irene van Staveren
}

Published online: 28 September 2007

(C) Springer Science + Business Media B.V. 2007

\begin{abstract}
The objective of this paper is to provide an insight into the ethics in the works of Christian economists in The Netherlands. The paper starts with a brief review of some key texts by Dutch Christian economists representing faith-based organizations. The next section presents a summary of (Dutch) Christian ethics, distinguishing four approaches: motivation, values, institutions, and instrumentalism. The following section will discuss some recent scholarly texts by Dutch Christian economists. It will be shown that three of the four ethical approaches are represented in these writings. In a comparison of the texts, the faith-based civil society economic thought seems to remain closer to the Christian ethics tradition. The last section will explain this gap by showing how, in faith-based civil society, morality is largely understood as being part and parcel of the economy, whereas in the academic economic literature, morality is largely regarded as belonging to the private sphere.
\end{abstract}

Keywords Christian economic thought $\cdot$ Christian ethics $\cdot$ Netherlands ·

Civil society organizations

\section{Christian Critiques of the Economy in The Netherlands}

This section will briefly review some Christian-inspired critiques of today's Dutch economy in which the market has obtained an increasingly important role since the 1980s. At the same time, the critiques also challenge mainstream economic thought and institutions and policies representing a mainstream view. Of course, Christian critiques

An earlier version was presented at a seminar about the market in The Netherlands, Utrecht University, March 2006. The author is grateful for useful comments provided by Wilfred Dolfsma, Ewald Engelen and Marieke de Goede at that seminar, and also for valuable comments on a revised version of the paper by Johan Graafland. The author also appreciates the comments and suggestions made by two anonymous referees of this journal.

I. van Staveren $(\bowtie)$

Department of Management Sciences, Radboud University, P.O. Box 9108, 6500 HK, Nijmegen,

The Netherlands

e-mail: i.staveren@chlello.nl 
of the economy and economics is not new, nor exclusively Dutch - see, for example, excellent publications such as Hoksbergen (1994) and Hay (1989). But it is striking to see how influential Dutch Calvinist critiques, in particular those following Abraham Kuyper (1837-1920), have been inside as well as outside The Netherlands (see, for example, Tiemstra et al. 1999; Tiemstra 1999; van der Vyver 2002; Heslam 2002). Below, I will discuss a selection of key texts from major faith-based civil society organizations in The Netherlands concerned with poverty, inequality, and the gap between rich and poor countries.

A first key text is the 1992 "Letter of Faith" on the Dutch economy (Agelink 1992). This critical pamphlet against the dominant role of the market was initiated by members of a working group of economists and theologians, of which two emeriti professors of economics, Harry de Lange and Bob Goudzwaard (both students of Nobel Prize winner Jan Tinbergen), are prominent members. The Letter was co-written with representatives of several faith-based civil society organizations. In 1996, it was followed by an "Open Letter" (Scharrenborg and van Workum 1996), stemming from consultations with a wider range of faith-based and secular organizations, including a Christian employer's association and Christian entrepreneurs and representatives of business, who were dissatisfied with some of the critiques of the first letter.

The Letter of Faith expresses a forceful critique of the market economy as it has been shaped by liberalization and privatization policies by every Dutch government since the 1980s, which most of the time included the Christian democrats. The critique is twofold: first, the letter signals that the market is only beneficial for those with property or sufficient purchasing power, and hence, not for the structurally unemployed or for welfare-dependent mothers with little labor-market experience, and neither for the poor in the developing world. Second, the letter criticizes the negative external effects of markets for society - in particular increasing inequality - and for the environment. Instead, the Letter calls for justice in the economy: "to say 'no' to the seemingly selfevidence of markets, growth, and technological advancement" (Hoekstra 1999: 13).

The Open Letter that appeared four years later takes a less normative stance but instead signals a growing dispersion between the economy and morality. To be more precise, the letter states that economic values have come to dominate moral values, and that economic policies in The Netherlands give too much priority to (1) economic growth, (2) efficiency, and (3) individual autonomy. This leaves little space, according to the Open Letter, for the Christian ethical dimensions of modesty, equality, and solidarity. Both letters, and in particular the first one, call for a shift of the Dutch economy away from neoliberalism towards a "Sabbath economy" in which responsibility becomes the driving value, expressed in the Biblical calls to good stewardship and the preferential option for the poor.

Both letters, as well as many related writings by Christian organizations on specific economic topics, refer to Biblical texts, in particular those about Jesus' concern with the poor and the marginalized. The critics, however, are well aware that the Bible, and Christian ethics in general, may lead to different views on the economy, and hence, may support contradictory economic policies. Noordegraaf et al. (1997), for example, acknowledge that one's Christian ethics may point out that individual responsibility should be the guiding principle for economic behavior, while other interpretations would stress solidarity with the weak.

The Christian critiques of the market, as expressed in the two Letters, are clearly inspired by a concept of responsibility that is not individualistic, but social and Springer 
inclusive - that is, based on social justice, as the economists Goudzwaard and de Lange (1986) have argued in their path-breaking book on an "economy of care," which appeared in an English translation (Goudzwaard 1995). Their ideas, as well as the views expressed in the two Letters, have recently been elaborated upon by other Dutch Christian economists, expressing not only critiques but also developing alternative approaches to economics. A good example is former IMF economist Haan (2005) in his recent book on a "reverent economy." Haan, now chairman of the Dutch faithbased NGO Solidaridad, explicitly refers to the Bible in supporting the critique of neoliberalism and neoclassical economics. Moreover, he rejects the dominant paradigm in economic science, citing from Psalms 119: 99, 104 to defend his deviation from the neoclassical economic theory in which he was trained: "I have more understanding than all my teachers: for thy testimonies [are] my meditation." Such a heterodox economic perspective leads him to criticize common interpretations of money parables in the Bible, such as the Parable of the Talents (Matth. 13: 12 and 25: 29), as not being about profit making, but about spiritual wealth. Another Dutch Christian economist and anthropologist, Henk Tieleman, at Utrecht University, is equally critical of neoliberalism. In his contribution to a collection of short papers on solidarity, he criticizes the misinterpretation of Adam Smith's invisible hand as automatically beneficial, outside a moral context. Instead, he argues for substantial responsibility in economic policies, which goes beyond what he labels the functional responsibility of rational economic man, being concerned solely with his self-interest (Tieleman 1995). Finally, we find a critical contribution jointly written by theologian Toine van den Hoogen and economist Jan Peil, both from Radboud University Nijmegen, on mainstream economic thought (van den Hoogen and Peil 2001). Paralleling the Open Letter, they argue that values lose their meaning when dominated by the market paradigm. Interestingly, they also discuss Adam Smith, referring not only to The Wealth of Nations, but also to The Theory of Moral Sentiments and the recognition in both books that markets cannot flourish without being embedded in and functioning through a moral context. This leads them to reinterpret the freedom of economic agents in terms of the value of responsibility: they contend that only by acting in relation to others and respecting others' freedom will agents be able to give meaning to their own economic freedom, and hence, to their economic behavior. This reinterpretation of freedom is quite different from the laissez-faire freedom of mainstream economics, because it recognizes the moral content of the value of freedom.

In conclusion, the economic writings by Dutch Christian economists who engage with the work of faith-based organizations in the areas of poverty, inequality, and development, oppose the dominant role of the market, reject the neoclassical paradigm, and call for an economic science, institutions, and policies that do justice to the core elements of Christian ethics. In the next section, we will explore this ethics in more detail and briefly review how it has been understood and institutionalized in The Netherlands over the past decades.

\section{Christian Ethics in The Netherlands}

This article does not provide sufficient space for a balanced discussion of Christian ethics. Nevertheless, I will try to give a very brief summary, admittedly incomplete, of 
Christian ethics in the Dutch context. Very generally, it seems that we can distinguish four approaches: motivation, values and norms, institutions and an instrumental approach. It is important to note, that these are not mutually exclusive, but often overlap.

\section{Motivation}

First, there is the approach focusing on motivation, supported by Manenschijn (1989) and others. This approach focuses on the individual agent and the freedom and responsibility of individuals in social life. As Barth (1938) has made it clear in his theology, humans are responsible to God and God's Creation, and their behavior is motivated by this responsibility and stewardship. The relationship with God is the basis of moral motivation, inspired by atonement, and replaces the role of conscience in non-Christian and/or non-religious moral systems. This responsibility may even be regarded in economic terms as a debt to God, referring to the original sin, so that irresponsible behavior is not merely moral weakness but a sin (Schweiker 1995). Hence, it is not so much the contents of morality - its values and norms - that are typically Christian in this approach, but its motivation that distinguishes Christian ethics from other ethical traditions. This view is also supported by Küng and Kuschel (1993), who have empirically assessed that Christian values largely overlap with the values of other spiritual traditions in the Western world, ranging from Judaism to humanism. Indeed, in this approach, various Dutch theologians have argued that Christianity has no monopoly over a particular set of values (see, for example, Verdonk 1988). These values are widely shared in and beyond the Western world, as can be seen from the common historical roots of the three Abrahamite religions: Judaism, Christianity, and Islam. All three have their ethical roots in Greek philosophers such as Plato and Aristotle, and so has humanism. Hence, this approach to Christian ethics does not point at Christian values as the distinguishing feature, but claims that the root of Christian ethics can be found in the moral motivation of humans, which is based upon a relationship with God, and the responsibilities that follow from this relationship.

\section{Values and Norms}

Different from, but not always in contrast to motivation, the second approach is concerned with the core values of Christianity - in particular, the question of what is the good life in relation to God, following Augustine's thesis that the good life requires that one knows and wills the good (de Kruijf 1999: 24-25). So, this approach to Christian ethics goes beyond the Kantian approach of rationally formulated moral rules which assumes that individuals should have a strong character that prevents weakness of will. Critics of the Kantian emphasis on rules rather than on character argue that character deserves more emphasis in moral theory because, in the words of Alasdair MacIntyre, "no rule or set of rules by itself ever determines how to respond rightly" (1999: 93). Christian ethics acknowledges that we humans are weak and therefore dependent upon God, not only for learning about the good (through formulating moral rules) but also for wanting to be good through our free human will - however limited this may be, as Nietzsche has claimed. In such a relationship with God, responsible human beings receive God's mercy and forgiveness, helping 
them to adhere to Christian values. Moreover, as explained by Verdonk (1988: 96), the meaning of life resides in the understanding of an ontological supremacy of the good, that is, the understanding that good, in the end, will prevail over evil because evil lacks the creative power to gain over the good.

Hence, this approach is concerned with what Aquinas termed to be the three Christian virtues: faith, hope, and love. A more normative interpretation of the good life focuses on the Ten Commandments, and regards morality as a set of God-given norms. A less strict normative interpretation of Christian values has a superficial resemblance to the Kantian categorical imperative, in the Biblical Golden Rule (Matt. 7: 12), stating that one should "always treat others as you would like them to treat you" - but always in the face of God. But, whereas Kant's moral rule is exclusively based on reason, the Golden Rule allows for other faculties, such as emotion and intuition, with an eye for the context to which rules are applied. Hence, the values-and-norms approach to Christian ethics goes beyond an individual's motivation, but will neither just accept morality as given, but rather perceive values as shaped and shared in Christian communities, as MacIntyre (1987) has emphasized.

\section{Institutions}

The third approach of Christian ethics is more practical, and focuses on the moral institutions of Christianity embedded in the Christian community (Kuitert 1992). These are, of course, the church (in its diversity ranging from Roman Catholicism to various strands of Protestantism), the Bible, as well as related faith-based organizations. The Dutch society has a peculiar tradition of Christian pillars, following the more or less even split of Christian faith in the country between Catholics and Protestants. This tradition was particularly strong during the first half of the twentieth century, with each pillar - Catholic, Reformed, Methodist, Baptist and other Protestant denominations, as well as the non-religious pillar of humanism - having its own schools, social and sport clubs, newspapers, radio and TV stations, political party, trade union, employers' association, and sectoral associations such as farmers' and women's organizations. This has led to a pillarized institutional setting of Dutch society, of which many pillars still survive today, while new ones have been added (for example, Islamic schools, clubs, and TV stations). Every pillar distinguishes itself from the others by its own denomination, and tolerates the others doing the same, thereby structuring Dutch society horizontally - in relatively independent communities rather than vertically, in classes (for some clear expositions in English of the system of pillarization and the different but related view of sphere sovereignty, see Tiemstra 1999, and a special issue of the Journal of Markets and Morality, vol. 5, no. 1, 2002). It is this set of Christian institutions that guides moral behavior in the Dutch Christian community, from the private sphere - family life, in particular - to the public sphere of politics and the economy. Common in these institutions is the rejection of a dominant state in favor of the recognition of human beings as free and responsible, as ends in themselves and equal before God. The pillar-based institutions play some roles that in other countries are performed by the state. This is expressed in two typical Dutch Christian values: self-responsibility (as opposed to state responsibility) and subsidiarity (as the location of governance at the lowest possible level, in line with selfresponsibility). The norm of sphere sovereignty was introduced by the 19th century 
Christian politician Abraham Kuyper, while the idea of subsidiarity was first mentioned in Catholic Social Thought by Pope Pius XI in 1931 in his Quadragesimo Anno (see also Klamer et al. 2005: 8-9), but became part of Dutch Christian political thought around the same time as Kuyper's idea of sphere sovereignty.

\section{Instrumentalism}

The fourth approach, a minority view, is one in which the hope for eternal life becomes the only purpose of moral behavior. All moral behavior is instrumental to this goal, which requires individual sacrifice and may turn life into a pilgrimage, as expressed by Augustine and Calvin. This approach requires individuals to closely follow the Biblical guidelines for every sphere of life: family life, social life, as well as economic life. This approach to Christian ethics is sometimes regarded as egoistic because of its exclusive concern with salvation. Afterlife is important in Christianity, as rewards are promised in afterlife rather than in this life (Matt. 19: 29; Luke 18: 22), but most Christians believe that these rewards cannot be attained instrumentally. The critics hold that it is only by trying to be good for goodness' sake itself, through God's grace, not self-consciously, that virtue will arise (for example, Jesus spoke against selfconscious goodness in Luke 18: 9). According to Bernard Williams, grace in Christianity meant precisely that "there was no calculable road from moral effort to salvation; salvation lay beyond merit; and men's efforts, even their moral efforts, were not the measure of God's love" (1997: 64-65). This critique is challenged by referring to eternal life as a life of perfect love for everyone, which should not be reduced to one's individual salvation. So, although this approach seems the most individualist of the four, it does not entirely exclude concern with (the salvation of) others.

\section{Summary}

Although all four approaches can be found in Dutch Christian life, the last one represents a small minority. The other three find support and are often related, sometimes emphasizing individualism, as with the motivation approach, and other times stressing social dimensions as with the values and norms approach and the institutional approach. In summary, Christian ethics in The Netherlands largely seems to be a mix of the first three approaches mentioned above, in which Christianity is believed to provide (a) moral motivation by the recognition of a responsibility vis-à-vis God, (b) a set of values and norms to guide one's free will, and (c) a set of institutions that will protect members of the Christian community against sin.

In the next section, the attention will be shifted to scholarly texts by Dutch Christian economists. The Christian ethics reflected in these writings will be analyzed and contrasted with the views as expressed in the Letter of Faith and Open Letter and related texts by faith-based organizations introduced earlier.

\section{Christian Ethics and Economics in The Netherlands}

Although various Dutch economists are Christian, and their scholarly work shows explicitly or implicitly - the influence of Christian ethics, there are no scholarly 
publications, to my knowledge, that discuss this influence (there is, however, a small network of Economics and Christian Ethics at http://www.uvt/ece.nl). This section, therefore, is a first attempt to reflect on the Christian ethics expressed in Dutch scholarly economic literature (published in Dutch and English).

Interestingly, and contrary to the international literature, we do not find examples in the Dutch literature supporting the instrumentalist approach of Christian ethics. Although there is some appreciation of the relevance of this literature (Fase 2005), no Dutch economist to my knowledge has followed in the footsteps of Azzi and Ehrenberg (1975), who extended a standard rational choice model with expected afterlife utility, dependent upon church attendance and religious donations. The aversion of Dutch economists to a rational choice approach to faith is probably related to an apparent shared interest to move beyond a narrow neoclassical model, towards (new) institutional economics (Bovenberg and van de Klundert 1999; Garretsen and Peil 2001). At a conference entitled "God in Economics?" held in 2004 in Nijmegen, the American theologian William Schweiker (2004) argued that a utilitarian interpretation of Christian ethics would go against the very values that Christianity promotes, and therefore, "will not satisfy the soul." The Dutch economists who were present at the conference seemed to agree with this position. Morality, according to Schweiker, relates to the penultimate ends of human activity and requires us to strife for the good in this life (Schweiker 1995; 2004).

What about the other three approaches to Christian ethics distinguished in the introduction? For each of these, we do find applications in Dutch economic literature.

\section{Motivation}

In the 2002 annual collection of short articles published by the Dutch Royal Society of Economics, theologian Manenschijn reacts to a (partially Christian-inspired) pamphlet titled "Stop the Sales of Civilization," a plea against further privatization and liberalization of the Dutch economy. Manenschijn argues, referring to Adam Smith, that the market cannot function without an ethical framework, but he disagrees with the view, expressed in the pamphlet as well as in the Letter of Faith and the Open Letter, that the market itself has a moral dimension. Instead, he claims "the functioning of the market as an allocation mechanism and price mechanism is a neutral instrument" (2002: 150). In this view, shared by the neoclassical school, morality only enters through the motivations of agents operating in markets, expressed in their choices of supply and demand. Hence, Manenschijn concludes, it depends on the motivations of agents whether markets will have socially beneficial outcomes or not, and not on the extent to which the economy is organized through the market mechanism.

It is unclear, though, how such as pluralist view of motivation can be reconciled with the common assumption of self-interest in mainstream economics. Two wellknown Dutch economists, Bovenberg and van de Klundert (1999), therefore reject this motivational approach and instead point to new institutional economics, in particular transaction cost economics, in order to reconcile the market with morality. They state that instead of having a well-ordered preference function, economic agents are torn between contradictory desires and are therefore vulnerable to 
temptations. They refer to the Bible as a source for developing appropriate preferences, as guidance for agents' decisions. Such moral motivation will, in turn, provide a solution for market failures, as it will reduce the temptation for free riding and the neglect of externalities, while mutual trust and cooperation will help to reduce transaction costs. From this perspective, Bovenberg and van de Klundert claim that while markets provide the incentives for efficiency, Christian ethics will enable markets to overcome market failures. Hence, Christian ethics and markets are regarded as complementary, with the first supporting the functioning of markets and the second providing the incentives for the maximization of welfare as a contribution to the Christian good life.

This view, however, still regards markets as morally neutral: it is market failures that are regarded as problematic, and which Christian norms will help to repair, and not the functioning of fully competitive markets themselves. Graafland (2000) puts the finger on the weak spot of the neutral-market-versus-moral-agent approach. He admits that, even in the absence of market failures, markets may make it very difficult for agents to act out their moral motives. In fact, in the context of highly competitive markets, Graafland states, agents may perceive a very small range for acting according to their moral motives. So, morality may, as Bovenberg and van de Klundert have claimed, indeed help markets to function better by reducing market failures, but when they function well, they may not allow for motives other than cost reduction and profit maximization, if agents are to survive competition. How then can this moral dilemma be addressed?

An alternative approach is provided by van den Hoogen (2001) and van den Hoogen and Peil (2001), parallel to van Staveren's (2001a) conceptualization of "meaningful rationality" as driven by agents' commitments to shared values. Van den Hoogen and Peil propose a re-conceptualization of economic rationality away from self-interest and utility maximization, and toward a hermeneutic perspective of rationality. Such hermeneutic rationality involves a search for meaning by agents when they make choices in markets. This re-conceptualization of rationality recognizes that economic agents in the real world are not simply utility-maximizers and often do not follow their self-interest, as has been demonstrated in experimental game theory and economic psychology. Agents are not autonomous, nor do they wish to be independent from others, but they are social beings and value relationships and the values that are shared in these, also when relationships are expressed through markets. Hence, markets do not only involve an exchange of goods for money, but also an interchange of values, and it is the combination of the two processes that provide meaning, they argue. Moreover, van den Hoogen and Peil (2001) contend that human motivation is not merely an individual disposition, ranging from egoism to altruism, but develops in close relation to society. As such, economic actors recognize other actors in markets as free human beings also, deserving respect, as in Smith's notion of mutual sympathy. This re-conceptualization of rationality, allowing for moral motives, challenges interpretations of Smith's view of markets as being morally neutral. Instead, van den Hoogen and Peil make clear that the combination of Smith's writings on economics and ethics implies an understanding of markets as having moral dimensions itself, affecting livelihoods and poverty, as well as a country's level of development. 


\section{Values and Norms}

Whereas the main Christian values are generally acknowledged to be the three virtues of faith, hope and love, also values and norms of justice, solidarity and benevolence are important Biblical values and feature in the writings of economists (see, for instance, de Jong 2002). For example, the norms of the Sabbath year (every seventh year) and the Jubilee year (every 50 years) are emphasized in publications by van Drimmelen (1998), de Jong and Klop (2000), and Haan (2005). In particular, de Jong and Klop recognize the value of justice in the Jubilee through redistribution of land and property to prevent accumulation by the rich at cost of livelihoods of the poor. They emphasize that such redistribution should not be implemented as a form of charity, but to enable the poor to access resources and to make these productive; they appeal to responsibility, by the rich and by the poor. This is, they remind us, because land is not owned by human beings but belongs to God's creation, over which we have only stewardship. Hence, we have the moral obligation to use creation's resources without wasting them - a concept in which we recognize a Christian notion of efficiency (for an elaboration of this point, see van Staveren 2008). At the same time, however, de Jong and Klop (2000) emphasize that markets provide the best guarantee for such efficient allocation of resources. They therefore argue that any redistribution in favor of the poor should not interfere with free markets, and hence, that debt cancellation should be applied only to a limited extent. If all poor countries' debt would be forgiven, they argue, this would give a perverse signal to financial markets which would result in even less access to finance for these countries.

Contrary to this position, the Dutch Jubilee 2000 campaign favors a much more generous forgiving of developing countries' debts. The campaign does not pose justice against efficiency, as de Jong and Klop do, but instead argues that redistribution will have long-run economic benefits. The Jubilee 2000 campaign receives support from a game theoretic experiment by $\mathrm{Wu}$ and Axelrod (1995), which has indicated that forgiveness leads to better outcomes than retaliation, as expressed in the famous tit-for-tat strategy in solving the Prisoner's Dilemma. This is because forgiveness helps to restore trust and cooperation quicker after a default by one of the players. In the Jubilee 2000 policy document "Our Fault, Their Right," Bökkerink (2003) states that poor countries' debts prevent them from investing in social sectors (such as health and education). Debt servicing takes up a large share of the budget, it lowers import capacity, which in turn constrains the availability of productive resources and technological advancement, and high public debt prevents domestic savings from staying in the country and reduces the inflow of foreign investment because of perceived risks of high taxation and limited complementary public investment in infrastructure. Moreover, the Jubilee 2000 report refers to the United Nations, which found that debt relief is more efficient than development aid because it provides more flexible funding and is not tied to donor interests. But the Jubilee 2000 campaign also addresses the issue of moral risk that creditors have deliberately taken by lending money to non-democratic regimes, arguing that this risk should not be shifted to the poor populations of indebted countries. The report argues that the irresponsibility of creditors has resulted in the moral hazard of 
over-lending in a continuous cycle of repayment of old loans with new loans. In other words, and contrary to the arguments made by de Jong and Klop, the Jubilee 2000 campaign argues that not canceling the debt of poor countries will be less efficient for these countries' development, keeping social investment low, chasing away domestic savings, and discouraging the inflow of investment and technology.

\section{Institutions}

The typical Dutch system of pillarization is the foundation not only for institutions in religious, social and political domains, but also for many socio-economic institutions. In particular, these institutions partially replace, or at least reduce, the role of the state while strengthening the role of civil society in the economy (Balkenende 1997; Balkenende and Tieleman 2001).

The typical Dutch Christian institutions have been recognized and studied by various economists, often from a neo-institutional perspective. The roots of institutional economics, going back to old institutional economics of Thorstein Veblen, tend to be ignored. Van de Klundert (1999) is rather negative about old institutional economics, regarding it more as a critique of neoclassical economics than as providing insights of its own. He states that old institutional economics "stresses the importance of institutions, but insufficiently formulates a theory, if any at all" (van de Klundert 1999: 133). At the same time, however, he approvingly refers to "Veblen goods" in his discussion of institutions affecting consumption (Bovenberg and van de Klundert 1999: 451). Others employ the notion of social capital to hypothesize a positive effect of church membership on the economy (Fase 2005). The literature tends either to focus on institutions that are closely linked to the market, or it analyzes institutions that regulate the private sphere.

The first strand of literature analyzes how institutions contribute to the functioning of markets, in terms of competitiveness, productivity, and efficiency. A good example of self-responsibility instead of state regulation is in the area of labor market regulation. The polder model of tripartite consensus between employers and employees, in which the state takes a backseat, is responsible for many Dutch labor market outcomes, such as wage moderation, a shorter workweek, and a fast increase in part-time work. These socio-economic institutions clearly reflect the typical Dutch Christian value of selfresponsibility as van der Toren (1997) has explained.

Another example, regarding international capital markets, is expressed in a paper by de Jong (2001), in which he argues against state regulation and emphasizes selfresponsibility of agents in financial markets, with self-regulation of the major institutions such as banks, towards limiting risks of financial crises. The lessons of the 1997 Asian financial crisis, however, have led otherwise enthusiastic defenders of full liberalization to plea for more rather than less state regulation (Bhagwati 2004; Stiglitz 2002). Also, the critical Christian literature on financial markets points out that, although these are among the most perfect markets, they have serious negative effects. These are caused not by regulation or institutional rigidities, but rather are inherent in the financial market processes themselves: being driven by short-term profit-seeking though speculation, not enhancement of production; vulnerability to devastating psychological effects of herd behavior which lead to bubbles and bursts; 
and backed by the powerful interests of what free trade proponent Bhagwati names the Washington-Wall-Street-Complex of the IMF, US Treasury, and the New York Stock Exchange, creating moral hazard and shifting risks to small scale entrepreneurs, the unemployed and generally the poor in developing countries. Another paper favoring market liberalization from a self-responsibility and subsidiarity perspective goes further than de Jong, ascribing positive moral value to free markets. In that paper, entitled "Competition: Necessary, Fair, and Just," Bakker et al. (1997) contend that competition provides equal opportunities and supports individual responsibility and freedom, but it does not provide much argument for this position.

The two Letters, however, signal that highly competitive markets may undermine these very values and even more so in a globalized world (see also Goudzwaard 2004, and Haan 2005). Competition in a context of inequality of access to and command over resources tends to lead to a cumulative accumulation of market power and wealth through mergers and acquisitions. Moreover, competition in a globalized world with highly mobile capital and restricted labor mobility results in asymmetric bargaining power between capital and labor. In addition, competition is not limited to a downward pressure on costs and prices, but also tends to extend to the creation of market segmentation through product differentiation and marketing, and to the exclusion of particular groups of people as workers (the less productive) or consumers (those with low purchasing power). Finally, highly competitive markets, such as financial markets, appear to generate greater volatility compared to regulated markets, with significant negative real effects. The critical Christian economic literature, therefore, does not share the view that markets are neutral - let alone benign - but acknowledges that even the most competitive markets inherently generate inefficiencies and reinforce inequalities.

A second set of Dutch Christian institutions relates to the household economy, expressed as a coherent set of norms that protect and support traditional family life. The ideal of the breadwinner and fulltime housewife was realized in The Netherlands in the mid-twentieth century, through a combination of a strong motherhood ideology and high productivity growth, allowing for a family wage, as Plantenga (1993) has demonstrated (until the 1950s there was a law prohibiting women to work for the state when they got married). The result for the economy was very low female labor force participation, despite high educational attainments for women and, in the 1960s and 1970s, a tight labor market, which was solved through immigration. As Plantenga argued in a later publication, the pillarized Christian institutions have played a key role in sustaining the traditional household division of labor: "In all probability, pillarization was extremely conductive...the pillars...offered channels for communicating attitudes from above, by imposing them forcefully on the whole population. Local level research, especially, makes clear how fine-meshed and interwoven were the relationships between clergy, manufacturers and social institutions, and with how much force the bourgeois ideal of the woman as full-time housewife, spouse and mother was put into practice by means of prohibitions, mutual agreements and continual debate" (Plantega 1998: 60). In a comparative study of Christian democratic welfare states, van Kersbergen (1995: 175) even concludes that "the Dutch welfare system became a 'breadwinner' system par excellence" with strong state support through tax-benefits for breadwinners until 
very recently, and low financial support for formal childcare and other forms of care. It was only in the 1990s that this system became less dominant, and transformed to a one-and-a-half-earner system, in which, today, the majority of working Dutch women has a part-time job (Plantenga 2002).

In an elaborate general equilibrium model, Graafland et al. (2001) have studied the labor market behavior of men and women. The analysis focuses on households, and assumes individual maximizing behavior within households. It does not make explicit distinctions between individual preferences and social norms, thereby implying that the gender division of labor is largely a result of independent choices made by men and women. Graafland (2001) elaborates on the model with explicit Christian norms, and compares the old with the new household division of labor. He concludes that the breadwinner model is no longer ideal, but in his view neither is the dual earner model. Instead, he favors the one-and-a-half earner model and the combination model (of two equal large part-time jobs). The one-and-a-half earner model is introduced in gender-neutral terms of a "breadwinner" and a "partner," but is defended among others, with the argument that it allows "the woman to invest in the marriage" (Graafland 2001: 159), which leaves the male role as investor in the marriage somewhat out of the picture. The widespread occurrence of the one-and-ahalf earner model in The Netherlands is, however, not explained in the model by social norms about gender roles, but by an apparent bounded rationality of women, who invest less in labor market experience than men by having part-time jobs. The conclusion does not refer to constraining gender norms but states that "women will probably not sufficiently recognize the long run effects" of their part-time rather than fulltime employment (Graafland 2001: 163).

The suggestion that Christian ethics favors the one-and-a-half earner model over the dual earner model, and that it is the result of independent individual choices of men and women, with women's choices affected by bounded rationality, has been challenged. Van Staveren (2001b) argues that the outcome of Graafland's model exercise is partly the result of the model's methodological individualist structure. In more detail, the feminist critique of this model by Plantenga, van Staveren and others, concerns the joint household utility function the model uses, which conceals intra-household distributional aspects of costs and benefits of unpaid work; treats unpaid work as, on the average, generating positive utility for the care giver; and models childcare as leisure time. In addition, Plantenga challenges the assumption of mutual insurance in marriage, given the high divorce rate in The Netherlands (around 33\%) and the increase in female-headed households. Both the breadwinner model and the one-and-a-half-earner model make women financially dependent upon men, which leads to female poverty upon the break-up of marriage (Plantenga 2002). This is precisely the critique coming from the faith-based organization EVA, concerned with women's poverty in The Netherlands, pointing out that elderly women who married in the institutional context of the breadwinner model now often find themselves with very meager financial support when they are no longer married.

Moreover, both models of the gender division of labor in Dutch households result in a high burden for women of unpaid caring work, as Bettio and Plantenga (2004) have demonstrated in a comparative study. Data for an index of unpaid caring for children, the disabled and the (chronically) ill show that The Netherlands has the highest share of self-care (compared to care provided by the state or services offered 
in the market) among 14 Western European countries. The index is $100 \%$ for The Netherlands, against, for example, $67.5 \%$ in Germany and $22.9 \%$ in Denmark (Bettio and Plantenga 2004: 88). The working group EVA points out that women deserve more appreciation for this "work of love," without necessarily implying that women should get paid for it. Rather, EVA calls for a fairer distribution of caring between women and men, with more financial support from the state, as well as a better balance between paid and unpaid work for everyone, because, as they argue, both types of work are valuable.

Viewed together, the two strands of literature on Christian institutions - those governing markets and those governing the household - again show the split between those who regard the market as morally neutral, with the private sphere providing a moral complement, in particular through women's traditional role of caring, and those who recognize that markets entail inherent, morally-laden processes.

\section{Conclusion}

The brief and admittedly sketchy discussion of Christian economic thought in The Netherlands in this paper distinguished between critical perspectives of faith-based civil society organizations and initiatives, on the one hand, and scholarly work by Christian economists, on the other. Of course, the two categories are not mutually exclusive, as we have seen, because some economists publish in both arenas. But generally, it seems fair to say that the texts by faith-based organizations and initiatives are more critical than the scholarly literature, although in the last category there is a clear diversity in views of the economy, the role of the market, and economic theory. Both strands of thought appear to conceptualize Christian ethics in terms of motivation, values and norms, and institutions.

However, the ways in which they analyzed these three approaches appear to be quite distinct. The difference stems from a clearly different view of the relationship between the market and morality. Whereas in the scholarly literature, the two are perceived as complementary, with the private sphere providing the moral context in which markets perform a morally neutral task, the critical literature understands the two as closely related, entangled as it were, so that markets simply cannot function neutrally. Interestingly, the scholarly view's dominance in Dutch Christian economic thought has been confirmed by a recent report on norms and values in Dutch society, by the Scientific Council for Policy (WRR 2003), as Fase (2005) has noted. The report limits its discussion of values and norms almost exclusively to the private sphere of families and communities. By way of exception, the report signals (but does not discuss) that liberalization and privatization policies may undermine values of equality and professionalism, for example in health care (WRR 2003: 147, 201). The policy report therefore appears to provide a fairly accurate picture of the dominant view of the relationship between markets and morality expressed in policies by the Christian Democratic coalition government, shaping an increasingly privatized and liberalized economy, for example in transport, housing, energy, and health care, while at the same time setting up an ambitious national "norms and values debate," urging Dutch citizens to behave according to norms of respect, honesty, politeness, and decency. But it is precisely this market-morality split 
underlying changes in the Dutch economy since the 1990s that led to the Letter of Faith and Open Letter and related critical writings from which this paper started. Hence, more analysis is needed in order to find out how the market/morality relationship is developing in Dutch Christian economic thought, civil society, and policies.

\section{References}

Agelink, D. (ed.) (1992). De Keerzijde van de Economische Medaille. Een Geloofsbrief over de Nederlandse Economie. Amsterdam: DISK.

Azzi, C., \& Ehrenberg, R. (1975). Household allocation of time and church attendance. Journal of Political Economy, 83(1), 27-56.

Bakker, C. J., Horsten, M. M., \& Kimman, E. J. J. M. (1997). Mededinging: Noodzakelijk, Fair en Rechtvaardig. In J. P. Balkenende, E. J. J. M. Kimman \& J. P. van den Toren (Eds.), Vertrouwen in de Economie Het Debat (pp. 84-99). Assen: van Gorcum.

Balkenende, J. P. (1997). Economie en ordening. In J. P. Balkenende, E. J. J. M. Kimman \& J. P. Van den Toren (Eds.) Vertrouwen in de Economie. Het Debat (pp. 9-25). Assen: van Gorcum.

Balkenende, J. P., \& Tieleman, H. (2001). Soevereiniteit in Eigen Kring, Subsidiariteit en Economische Orde. In M. Becker, H. Garretsen, T. van den Hoogen, K. Klop, J. Peil \& K. Rijnvos (Eds.), Economie en Ethiek in Dialoog (pp. 194-210). Assen: van Gorcum.

Barth, K. (1938). Die Kirchliche Dogmatik, EVZ/TVZ: Zurich.

Bettio, F., \& Plantenga, J. (2004). Comparing care regimes in Europe. Feminist Economics, 10(1), 85-113. Bhagwati, J. (2004). In defense of globalization, Oxford: Oxford University Press.

Bökkerink, S. (2003). Onze Schuld Hun Recht. Utrecht: Jubilee Nederland.

Bovenberg, A. L., \& van de Klundert, Th. C. M. J. (1999). Christelijke Traditie en Neoklassieke Economie in Gesprek. Economisch Statistische Berichten, 84(4230), 848-852.

de Jong, E., (2001). Internationale Economische Gerechtigheid en Vrij Kapitaalverkeer. In M. Becker, H. Garretsen, T. van den Hoogen, K. Klop, J. Peil \& K. Rijnvos (Eds.), Economie en Ethiek in Dialoog (pp. 239-256). Assen: van Gorcum.

de Jong, E., (2002). Markt en Waarden. Nijmegen: Valkhof. Thijmgenootschap.

de Jong, E., \& Klop, C. J. (2000). Het Jubeljaar. Economisch Statistische Berichten, 85(4288), D21-D25. de Kruijf, G. G. (1999). Christelijke Ethiek. Een Inleiding met Sleutelwoorden, Zoetermeer: Meinema.

Fase, M. M. G. (2005). On economics and religion. De Economist, 153, 85-106.

Garretsen, H., \& Peil, J. (2001). Van Segregatie naar Reintegratie? In M. Becker, H. Garretsen, T. van den Hoogen, K. Klop, J. Peil \& K. Rijnvos (Eds.), Economie en Ethiek in Dialoog (pp. 10-38). Assen: van Gorcum.

Goudzwaard, B. (2004). "Globalisering en Economie vanuit Christelijk Perspectief," paper presented at a seminar of the network Economics and Christian Ethics, Tilburg: University of Tilburg.

Goudzwaard, B. (1995). Beyond Poverty and Affluence. Toward an Economy of Care with a Twelve-Step Program for Economic Recovery. In M. R. vander Vennen (Ed.). Grand Rapids: Eerdmans.

Goudzwaard, B., \& de Lange, H. (1986). Genoeg van te Veel-Genoeg van te Weinig. Baarn: Ten Have.

Graafland, J. (2000). Waar ligt de Motivatie? Economisch Statistische Berichten, 85(4288), D20.

Graafland, J. (2001). Tussen Kostwinner- en Tweeverdienersmodel. In M. Becker, H. Garretsen, T. van den Hoogen, K. Klop, J. Peil, \& K. Rijnvos (Eds.), Economie en Ethiek in Dialoog (pp. 154-178). Assen: van Gorcum.

Graafland, J., de Mooij, R., Nibbelink, A., \& Nieuwenhuis, A. (2001). MIMICing tax policies and the labour market. Amsterdam: Elsevier.

Haan, R. (2005). Economie van de Eerbied. Zoetermeer: Meinema.

Hay, D. (1989). Economics Today: A Christian Critique. Grand Rapids: Eerdmans.

Heslam, P. S. (2002). Prophet of a third way: The shape of kuyper's socio-political vision. Journal of Markets \& Morality, 5(1), 11-33.

Hoekstra, T. (1999). Economie en Geloven-Een Zoektocht naar een Kritische Theologie. Kampen: Kok.

Hoksbergen, R. (1994). Is There a christian economics? Some thoughts in the light of the rise of Postmodernism. Christian Scholars' Review, 24(2), 126-142.

Klamer, H., Dolsma, G., \& van den Braak, J-W. (2005). Perspectief op een Participatiemaatschappij. Assen: van Gorcum.

Kuitert, H. M. (1992). Het Algemeen Betwijfeld Christelijk Geloof. Baarn: Ten Have.

Küng, H., \& Kuschel, K-J. (1993). Global ethic-declaration of the parliament of world's religions. New York: Continuum. 
MacIntyre, A. (1987). After virtue a study in moral theory, 2nd edn. Londen: Duckworth.

MacIntyre, A. (1999). Dependent Rational Animals. Why Human Beings Need the Virtues. London: Duckworth. Manenschijn, G. (1989). Mogelijkheid en Noodzakelijkheid van een Christelijke Ethiek. Oratie. Kampen: Kok. Noordegraaf, H., Salemink, T., Tieleman, H., \& van Eelderen, R. (1997). Ter Inleiding. De Moderne Economie als Juggernaut en de "Verlegenheid" van de Theologie. In H. Noordegraaf (Ed.), De Moderne Economie als Juggernaut. Het Debat over Theologie en Economie. Kampen: Kok.

Plantenga, J. (1993). Een Afwijkend Patroon. Honderd Jaar Vrouwenarbeid in Nederland en (West-) Duitsland. Amsterdam: SUA.

Plantenga, J. (1998). Double Lives: Labour Market Participation, Citizenship and Gender. In J. Bussemaker \& R. Voet (Eds.), Gender, participation and citizenship in The Netherlands (pp. 51-64). Aldershot: Ashgate.

Plantenga, J. (2002). Combining work and care in the polder model: An assessment of the Dutch part-time strategy. Critical Social Policy, 22(1), 53-71.

Scharrenborg, H., \& van Workum, J. (eds.) (1996). Dienst aan het Leven. Open Brief over Economie als Zaak van Geloven. In A. M. Booij \& G. van Eck (Eds.), Dienst aan het Leven (pp. 9-16). Amsterdam: DISK.

Schweiker, W. (1995). Responsibility and christian ethics. Cambridge: Cambridge University Press.

Schweiker, W. (2004). God in Economics: Self-interest, the Common Good and Some Paradoxes. Paper prepared for the conference "God in Economics?, 17-19 June, 2004, Nijmegen University.

Stiglitz, J. (2002). Globalization and its discontents. New York: Norton.

Tieleman, H. (1995). Beschaving en Economie. In H. Crijns, H. Noordegraaf, T. Salemink \& J. van der Wal (Eds.), Solidariteit als Cement van onze Samenleving. Kampen/Utrecht: Kok/DISK.

Tiemstra, J. P. (1999). Every square inch. Kuyperian social theory and economics. In J. Dean \& A. M. C. Waterman (Eds.), Religion and economics: Normative social theory (pp. 85-98). Norwell: Kluwer.

Tiemstra, J. P., Graham, W. F., Monsma, G. N., Sinkey, C. J., \& Storkey, A. (1999). Reforming economics: Calvinist studies in method and institutions. Lewiston: Edwin Mellen Press.

van Drimmelen, R. (1998). Faith in a global economy. A primer for christians. Geneva: WCC Publications.

van Kersbergen, K. (1995). Social capitalism. A study of Christian democracy and the welfare state. London: Routledge.

van Staveren, I. (2001a). The values of economics: An Aristotelian perspective. London: Routledge.

van Staveren, I. (2001b). De Paradox van Zorgarbeid. In M. Becker, H. Garretsen, T. van den Hoogen, K. Klop, J. Peil, \& K. Rijnvos (Eds.), Economie en Ethiek in Dialoog (pp. 179-193). Assen: van Gorcum.

van Staveren, I. (2008). Efficiency as a Christian value. In T. van den Hoogen, J. Peil \& I. van Staveren (Eds.), God in economics? Leiden: Brill (forthcoming).

van de Klundert, T. (1999). Economic efficiency and ethics. De Economist, 147, 127-149.

van den Hoogen, T. (2001). Een Theologische Perspectief op Economische Rechtvaardigheid. In M. Becker, H. Garretsen, T. van den Hoogen, K. Klop, J. Peil \& K. Rijnvos (Eds.), Economie en Ethiek in Dialoog (pp. 54-77). Assen: van Gorcum.

van den Hoogen, T., \& Peil, J. (2001). De Interpreterende Agent. Economisch Statistische Berichten, 86 (4332), 846-48.

van der Toren, J. P. (1997). De Transformatie van de Overlegeconomie: de CAO. In J. P. Balkenende, E. J. J. M. Kimman \& J. P. van den Toren (Eds.), Vertrouwen in de Economie. Het Debat (pp. 136-152) Assen: van Gorcum.

van der Vyver, J. D. (2002). The jurisprudential legacy of Abraham Kuyper and Leo XIII. Journal of Markets and Morality, 5(1), 211-249.

Verdonk, W. E. (1988). Ongehoord. Uit de Nalatenschap van W. E. Verdonk (1928-1986). In A. Vos and C. van der Zwaard (Eds.). Den Haag: Boekencentrum.

WRR (2003). Waarden, Normen and the Burden of Behaviour, Amsterdam: Amsterdam University Press. Wetenschappelijke Raad voor het Regeringsbeleid.

Wu, J., \& Axelrod, R. (1995). How to cope with noise in the iterated prisoner's dilemma. Journal of Conflict Resolution, 39(1), 183-189.

Irene van Staveren The author is Professor of Economics and Christian Ethics at Radboud University Nijmegen. She teaches on ethics and economics and globalization, and currently edits, with Jan Peil, a handbook on ethics and economics. She also teaches at the Institute of Social Studies in the Hague. There, she teaches and does research on gender and economic policy, labour markets in developing countries, and social capital. She recently edited, with Peter Knorringa, a special issue on social capital for the Review of Social Economy (spring 2007). 